\title{
The in-plane electrical conductivity: the rotation parameters effect on producing graphite/epoxy composites
}

\author{
Hendra Suherman ${ }^{1 *}$, Andro Hamdani ${ }^{1}$, Edi $_{\text {septe }}{ }^{1}$, Yovial $^{1}$, Irmayani $^{2}$ \\ ${ }^{1}$ Department of Mechanical Engineering, Universitas Bung Hatta, 25143 Padang, Indonesia \\ ${ }^{2}$ Department of Industrial Engineering, Universitas Ekasakti, 25133 Padang, Indonesia
}

\begin{abstract}
The rotation parameters used to produce graphite/ epoxy composites material is greatly determine the properties of in-plane electrical conductivity. However, the appropriate rotation parameters are different for each composition, conductive materials, and matrix used. In this study, variations of rotation parameters $(250 \mathrm{rpm}, 350 \mathrm{rpm}$ and $450 \mathrm{rpm})$ and rotation time (5 $\mathrm{min}, 10 \mathrm{~min}$ and $15 \mathrm{~min}$ ) with constant molding parameter such as molding temperature $\left(150{ }^{\circ} \mathrm{C}\right)$, molding time (120 minutes) and molding pressure $\left(50 \mathrm{~kg} / \mathrm{cm}^{2}\right)$ have been used to produce graphite/epoxy composites. The results showed that the highest in-plane electrical conductivity $65 \mathrm{~S} / \mathrm{cm}$ on the resulting graphite/epoxy composites.
\end{abstract}

\section{Introduction}

Rotation parameters, such as rotation time, rotation speed, and temperatures during rotation are the significant parameters affecting the quality of the resulting composite material [1-5]. The dispersed or coagulated filler or conductive material in the matrix were greatly depends on the mixing parameters used in producing the composite material $[1,2]$. Mixing matrix and filler can be done using different method and parameter variation. In situ polymerization and melt mixing compounding have been used to mix matrix as a binder and filler as conductive material [6-8]. Hu et al. [1] found that short rotation processes using modest shear forces increased the formation of conductive networks within the matrix. Meanwhile, high-speed stirrer can produce a homogeneous dispersion of filler, resulting in higher in-plane electrical conductivity [9]. Suherman et al. [10] using carbon nanotubes (CNTs) as a second filler in producing CNTs/graphite/epoxy composite using Taguchi method. They found that the electrical conductivity was significantly influenced by the rotation parameters in generating conductive networks. Zakaria et al. [11] conducted a study on the effect of rotation parameters on the electrical conductivity of carbon black/graphite/epoxy nanocomposites using Taguchi method. The results showed that the significant agitation parameters affect the electrical conductivity produced. These previous researches use multi filler in investigating the effect of rotation parameters on the electrical conductivity. This study use $80 \mathrm{wt} . \%$ single filler of high conductive filler to investigete the

\footnotetext{
*Corresponding author: hendras@bunghatta.ac.id
} 
effect of rotation parameters in producing graphite/epoxy composite material to the in-plane electrical conductivity.

\section{Experimental procedure}

\subsection{Materials}

Graphite is obtained from Asbury Carbons, Inc. U.S. Graphite type 635 fine flake has particle size of $150 \mu \mathrm{m}$ is used in this study. The 635 thin epoxy resin, with a viscosity of 6 poise, and fast epoxy hardener was obtained from US Composites.

\subsection{Fabrication of graphite/epoxy composites.}

The composition of graphite and epoxy used to produce graphite/epoxy composite is $80 / 20$ by weight percent (wt.\%). In the early stage, epoxy and hardener are mixed in a 4: 1 composition based on weight percent (wt.\%), as recommended by the manufacturer. The mixture was stirred using a RM 20-KIKA-WERK mechanical stirrer at $200 \mathrm{rpm}$ for 5 minutes. On the next step, $80 \mathrm{wt} . \%$ of graphite as a conductive filler is stirred with various rotation speeds $(250,350,450 \mathrm{rpm})$ and various rotation times $(5,10,15$ minutes $)$. Furthermore, the mixture was poured into an aluminum mold at constant molding parameters of molding pressure $50 \mathrm{~kg} / \mathrm{cm}^{2}$; molding temperature $150^{\circ} \mathrm{C}$; and molding time 120 minutes.

\subsection{Characterization}

ASTM C 61 standard is used to measure the in-plane electrical conductivity of graphite/epoxy composites.

\section{Results and discussion}

\subsection{Effect of rotation speed on the in-plane electrical conductivity}

The effect of rotation speed on the in-plane electrical conductivity of the graphite/ epoxy composites material is shown in Figure 1. Figure 1 shows three variations of rotation speed ( $250 \mathrm{rpm}, 350 \mathrm{rpm}$ and $450 \mathrm{rpm}$ ) at constant rotation time of $5 \mathrm{~min}$. 


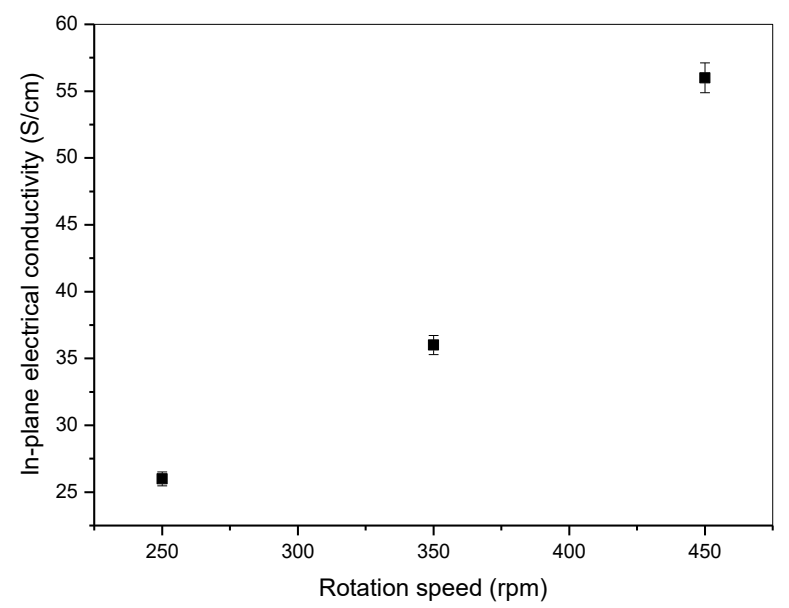

Fig. 1. Effect of rotation speed on the in-plane electrical conductivity

The in-plane electrical conductivity of graphite/epoxy composite at rotation speeds of 250 $\mathrm{rpm}, 350 \mathrm{rpm}$ and $450 \mathrm{rpm}$ sequentially are $26 \mathrm{~S} / \mathrm{cm}, 36 \mathrm{~S} / \mathrm{cm}$ and $56 \mathrm{~S} / \mathrm{cm}$. The in-plane electrical conductivity increases by the increasing of rotation speed used. The increasing electrical conductivity due to higher rotation speed (ie $450 \mathrm{rpm}$ ) is capable to form a better conductive network. This resulted the highest rotation speed of $450 \mathrm{rpm}$ having the highest in-plane electrical conductivity $(56 \mathrm{~S} / \mathrm{cm})$ compared with $250 \mathrm{rpm}$ rotation $(26 \mathrm{~S} / \mathrm{cm})$ and $350 \mathrm{rpm}(36 \mathrm{~S} / \mathrm{cm})[1-3,5]$.

\subsection{Effect of rotation time on the in-plane electrical conductivity}

Figure 2. shows the effect of rotation time on the in-plane electrical conductivity of graphite/ epoxy composites. Overall, the in-plane electrical conductivity of graphite/ epoxy composites increase by the increasing of rotation time from 5 minutes to 15 minutes. This proves that rotation time significantly influences in forming conductive network within polymer matrix, resulting in higher in-plane electrical conductivity $[1,12]$ 


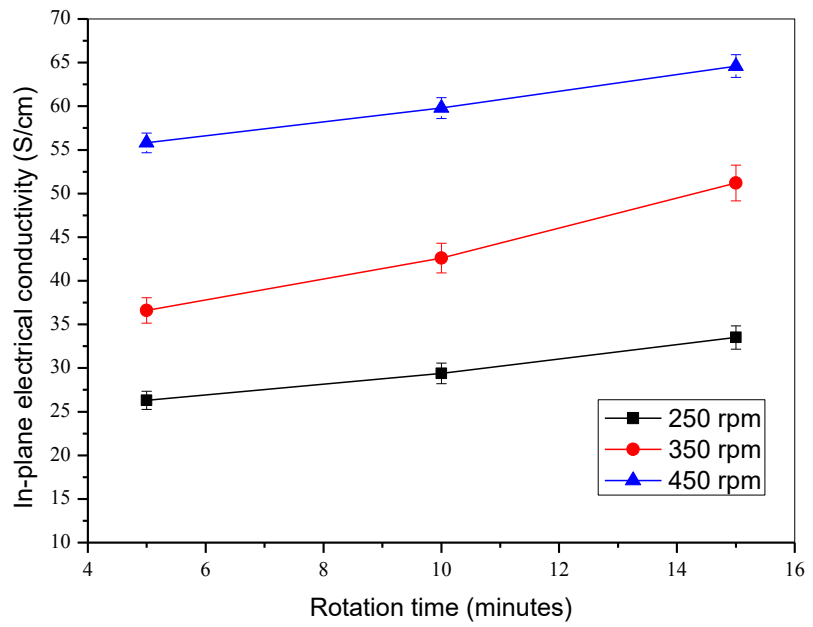

Fig. 2. Effect of rotation time on the in-plane electrical conductivity

At rotation speed of $250 \mathrm{rpm}$, in-plane electrical conductivity of 5 minutes $(26 \mathrm{~S} / \mathrm{cm})$ to 15 minutes rotation time $(33 \mathrm{~S} / \mathrm{cm})$ increased by $26.92 \%$. At a rotation speed of $350 \mathrm{rpm}$, the increase in in-plane electrical conductivity from $5 \mathrm{~min}(36 \mathrm{~S} / \mathrm{cm})$ to $15 \mathrm{~min}$ rotation time $(51$ $\mathrm{S} / \mathrm{cm}$ ) was $41.66 \%$, while at $450 \mathrm{rpm}$ rotation speed increased in-plane electrical conductivity from $5 \mathrm{~min}(56 \mathrm{~S} / \mathrm{cm})$ to 15 minutes $(65 \mathrm{~S} / \mathrm{cm})$ was $16.07 \%$. Thus, the largest increase in in-plane electrical conductivity with the increase of rotation time from 5 to 15 minute occurs at $350 \mathrm{rpm}$ rotation speed. However, the best in-plane electrical conductivity of graphite/epoxy composites is at a rotation speed of $450 \mathrm{rpm}$, and rotation time of $15 \mathrm{~min}$. The increase of rotation time is capable of generating more electrical conductivity network in the polymer matrix thus increasing the in-plane electrical conductivity to the resulting graphite/epoxy composites $[12,13]$.

\section{Conclusion}

Graphite/epoxy composites with simple methods have been produced. Some conclusions are:

1. The increasing of rotation speed (from $250 \mathrm{rpm}$ to $450 \mathrm{rpm}$ ) and rotation time (5 minutes to 15 minutes) increase the in-plane electrical conductivity of graphite/epoxy composites produced.

2. The highest in-plane electrical conductivity $(65 \mathrm{~S} / \mathrm{cm})$ is obtaine at 15 minutes rotation time and $450 \mathrm{rpm}$ rotation speed.

The author wishes to thank the Directorate General of Higher Education through the applied research of excellent university, so this research can run well based on the time set through contract number: 023-34/LPPM-Penelitian/Hatta/II-2018.

\section{References}

1. N. Hu, Z. Masuda, G. Yamamoto, H. Fukunaga, T. Hashida, J. Qiu, Compos. Part AAppl. S, 39, 893 (2008) 
2. P.C. Ma, M.Y. Liu, H. Zhang, S.Q. Wang, R. Wang, K.Wang, Y.K. Wong, B.Z. Tang, S.H. Hong, K.W. Paik, J.K. Kim, ACS Appl.Mater.Interfaces 1, 1090 (2009)

3. H. Suherman, A.B. Sulong, J. Sahari, Int. J. Mech. Mater. Eng. 5, 74 (2010)

4. H. Suherman, A.B. Sulong, J. Sahari. Adv. Mater. Res. 264-265, 559 (2011)

5. H. Suherman, A.B. Sulong, M.Y. Zakaria, N.R. Rajendra Royan, J. Sahari, Songklanakarin J. Sci. Technol. 40, 105 (2018)

6. H. Deng, T. Skipa, R. Zhang, D. Lellinger, E. Bilotti, I. Alig, T. Peijs, Polymer, 50, 3747 (2009)

7. M. Murariu, A.L. Dechief, L. Bonnaud, Y. Paint, A. Gallos, G. Fontaine, S. Bourbigot, P. Dubois, Polym. Degrad. Stabil, 95, 889 (2010)

8. Y. Pan, L. Li, S.H. Chan, J. Zhao, Compos. Part A-Appl. S, 41, 419 (2010)

9. X. Xie, Y. Mai, X. Zhou, Mat. Sci. Eng. R, 49, 89 (2005)

10. H. Suherman, J. Sahari, A.B. Sulong, Advan. Sci. Lett, 19, 334 (2013)

11. M.Y. Zakaria, H. Suherman, J. Sahari, A.B. Sulong, Appl. Mech. Mater, 393, 68 (2013)

12. R. Taherian, A.N. Golikand, M.J.Hadianfard, Mater. Design 32, 3883 (2011)

13. N.R. Rajendran Royan, A.B. Sulong, J. Sahari, H. Suherman, J. Nanomater, 2013 Article ID 717459 (2013) 